\title{
Towards a moss flora of Taif and its vicinities, Saudi Arabia. 1- Funariaceae
}

\section{Usama Y. Abou-Salama*, Abdel-Rahman A. Al-Humiany** and Hanaa M. Shabbara*}

*Faculty of Science, Ain Shams University, Cairo, Egypt

**Teacher's College, Taif, Kingdom of Saudi Arabia

E-mail: usamaabousalama@Yahoo.com

Abou-Salama U.Y., Al-Humiany A.A. \& Shabbara H.M. 2005. Towards a moss flora of Taif and its vicinities, Saudi Arabia. 1- Funariaceae. Taeckholmia 25: 1-14.

\begin{abstract}
Three members of Funariaceae are recorded for the first time from vicinities of Taif city; namely Entosthodon attenuatus (Dicks.) Bryhn., E. muhlenbergii (Turner) Fife and E. pulchellus (H.Philib.) Brugués. A key, descriptions, photos, distributional data, comments and maps indicating sites of collections are given.
\end{abstract}

Key words: Funariaceae, moss flora, Saudi Arabia

\section{Introduction}

El-Saadawi (1976) recorded many mosses from Kuwait, and mentioned that "nothing is known of the moss flora of Saudi Arabia and some other neighbouring countries". This comment stimulated bryological work in Saudi Arabia and the whole Arabian Peninsula which was thought to be a bryophyte desert.

In Saudi Arabia (four-fifths of the area of the Arabian Peninsula), the start was a record of Funaria pulchella H. Philib. (=Entosthodon pulchellus) by Townsend (1978). This was followed, two years later, by a series of papers published mainly by Frey and/or Kürschner on Bryophytes of Saudi Arabia and of some other countries in the Arabian Peninsula (Kürschner, 2000; Kürschner et al., 2001). In addition a paper on mosses of Ha'il in the central part of Saudi Arabia was published by Refai (2001). As 
a result, the number of mosses now known from Saudi Arabia amounts to 122 taxa included in 19 families.

Out of these 122 mosses of Saudi Arabia, 24 were recorded in localities near Taif (Frey \& Kürschner, 1988; Kürschner, 2000). They were collected from six regions; i) between Makkah and Taif (13 taxa), ii) near Al-Hada, west of Taif (five taxa), iii) Gebel Baydem, $30 \mathrm{~km}$ south of Taif (five taxa), iv) $20 \mathrm{~km}$ southwest of Taif (three taxa), v) $30 \mathrm{~km}$ north of Taif (one taxon) and vi) $30 \mathrm{~km}$ west of Taif (one taxon). The 24 mentioned taxa were identified to the specific level or lower and were found to represent seven families. In addition to these, one of the specimens collected from the region between Makkah and Taif was identified as Funaria sp. (Frey \& Kürschner, 1988) and was then the only representative of an eighth family, viz. Funariaceae.

Funariaceae is relatively rare in Saudi Arabia as a whole being represented, besides the above mentioned Funaria sp., by only five taxa, namely Entosthodon attenuatus (Dicks.) Bryhn, E. durieui Mont., E. muhlenbergii (Turner) Fife, E. pulchellus (H.Philib.) Brugués and Micropoma niloticum (Delile) Lindb. All these taxa (including Funaria sp.) were recorded from the Western Heights of Saudi Arabia except E. durieui which was reached on the eastern coast of the country (Kürschner, 2000).

This paper is concerned with family Funariaceae and is the first of a series aiming at the furtherance of our knowledge about the moss flora of Taif city and its vicinities. In this first paper, however, no Funariaceae were found in Taif city itself.

\section{Study area and Materials}

Taif city (Fig. 1) lies in about the middle of the Western Heights of Saudi Arabia which extend along the whole coast of the Arabian Peninsula. These Heights are known as Al-Hijaz mountains. The part of these mountains to the north of Taif is of much less height than the southern part which is, therefore called El-Sarawat mountains (Al-Welai'ee, 1997). These mountains are rugged and the highest in Saudi Arabia (up to 3015 m Above Sea Level "ASL").

Taif city (Fig.1) lies in the northern end of El-Sarawat mountains. It has an area of about $80 \mathrm{~km}^{2}$ and altitude of ca $1600-1700 \mathrm{~m} \mathrm{ASL}$. It is surrounded from the northern west to the south by a series of relatively high igneous 
and metamorphic mountains and volcanic rocks (Brown, 1960, Brown et al. 1962) which reach up to $2500 \mathrm{~m}$ ASL dissected by narrow and deep Wadis. Mosses in this work were collected from 9 sites, situated in four regions (Fig.2) as follows:

- Al-Hada urban region, northwest of Taif city. (sites 1-3, Fig. 2).

- Al-Sail El-Kabeer, just before Mequat Al-Sail, north of Taif city. (site 4, Fig.2).

- Al-Wakaf village, in the suburban region, west of Taif city, which is an open wide Wadi between relatively low heights.(site 5, Fig. 2).

- Al-Shafa, $22 \mathrm{~km}$ southwest of Taif city. (sites 6-9, Fig. 2).

The temperature of Taif city ranges from $23.2^{\circ} \mathrm{C}$ to $33.5^{\circ} \mathrm{C}$ in July, while in January it ranges from $9^{\circ} \mathrm{C}$ to $22^{\circ} \mathrm{C}$. Precipitation mainly in summer, occasionally in autumn and spring, rarely in winter and the mean total annual rainfall is about $180 \mathrm{~mm}$. Relative humidity in January reaches $56 \%$ while in July it is $27 \%$ (Al-Shareif, 1987). Fog and dew formation usually occur, especially in winter and sometimes after heavy rainfall intervals.

The high altitude of the present collection sites and their climatic conditions being rainy, cloudy, foggy and dewy afford habitats suitable for the growth of specific bryophytes.

From August 1999 to April 2003, a quite large moss collection was made (1350 samples) from Taif city and its vicinities covering various seasons and habitats. Specimens were numbered and kept at CAIA and duplicates in the private collection of the first author. These 1350 samples represent many moss families; out of which Funariaceae was represented by only 22 samples (i.e. $1.6 \%$ of the total collection). None of these Funariaceae samples came from Taif city itself but all from its vicinities.

\section{Results}

Plants of nine out of these 22 samples were young, fruitless and therefore disregarded. Investigation of the remaining 13 samples resulted in the recognition of three taxa namely: Entosthodon attenuatus, E. muhlenbergii and E. pulchellus.

According to Fife (1985) these taxa belong to two subgenera; subgenus Plagiodus and subgenus Entosthodon. The former includes E. muhlenbergii 
and E. pulchellus and is characterized by inclinated, asymmetric capsules and sigmoid exostome teeth. The latter includes Entosthodon attenuatus and is characterized by erect, symmetric capsules and exostome teeth, when present, with oblong exothecial cells.

Key, descriptions, sites, habitats, dates of collection, herbarium numbers, distributions (in neighbouring countries) and photos are provided for the studied taxa. The distribution of taxa is based on: Wijk et al. (195969), Frey \& Kürschner (1988); Kürschner (2001) and Shabbara \& ElSaadawi (2001). Abbreviations of countries are Ye: Yemen; UAE: United Arab Emirates; Om: Oman; Iq: Iraq; Sy: Syria; Le: Lebanon; Jo: Jordan; Ir: Iran; IsP: Israel and Palestine; Tu: Turkey; Soc: Socotra.

\section{Key to taxa of Funariaceae in the vicinities of Taif city}

1- Capsule symmetric, peristome single and rudimentary, operculum beakless ............................................... attenuatus

2- Capsule asymmetric, peristome double and well developed, operculum beaked

2-Leaf with long apiculate cell, margin toothed, basal cells distinctly large; seta up to $1.2 \mathrm{~cm}$ E. muhlenbergii

2-Leaf without long apiculate cell, margin entire, areolation \pm homogenous throughout; seta up to $0.7 \mathrm{~cm}$ E. pulchellus

\section{1-Entosthodon attenuatus (Dicks.) Bryhn. Plate (1)}

Plants autocious, male branch shorter than female one, and easily separated from it, male "flowers" obvious, yellowish green, tufted. Female stem up to $1.2 \mathrm{~cm}$ long, central strand well developed above but quite small toward base. Leaves erect, flat, spathulate, long ovate and lingulate, comal in female plants but usually \pm equally spaced in male ones, leaves of female plants larger than those of the males and up to $2.0 \mathrm{~mm}$ long; margin bluntly dentate above but entire below, cells narrower than laminal ones, but not forming a distinct border, unistratose, plane; apex acute to very short acuminate; costa ending below apex, slender; cells hexagonal and pentagonal, to $150 \mu \times 30 \mu$ above, long rectangular to $400 \mu \times 65 \mu$, sometimes lax at base. Sporophyte present, calyptra cuculate; operculum convex, beaked, with spirally arranged cells; seta erect, with a small central strand and thick walled epidermis, outer cortical cells, up to $1.5 \mathrm{~cm}$ high; capsule erect, pyriform, with long neck, symmetric, up to $2.8 \mathrm{~mm}$; 

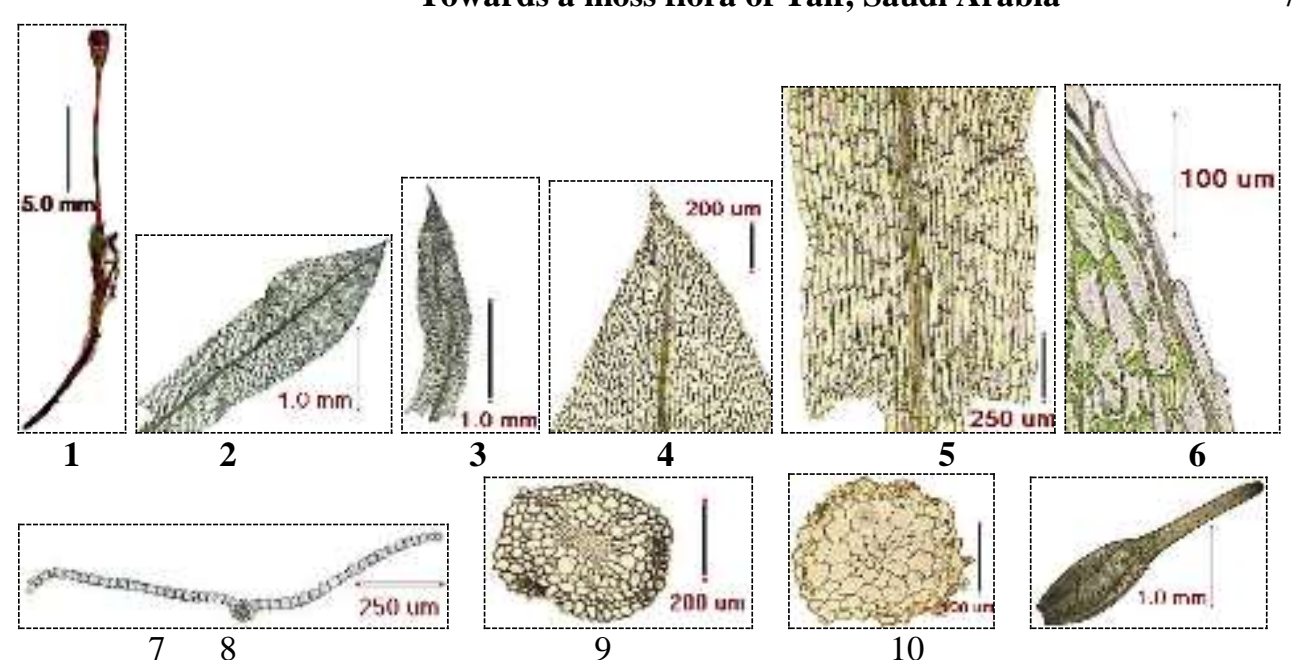

5
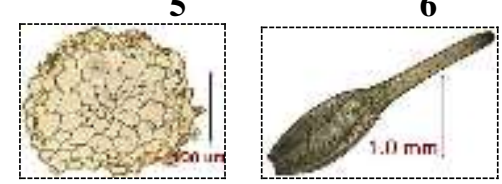

10
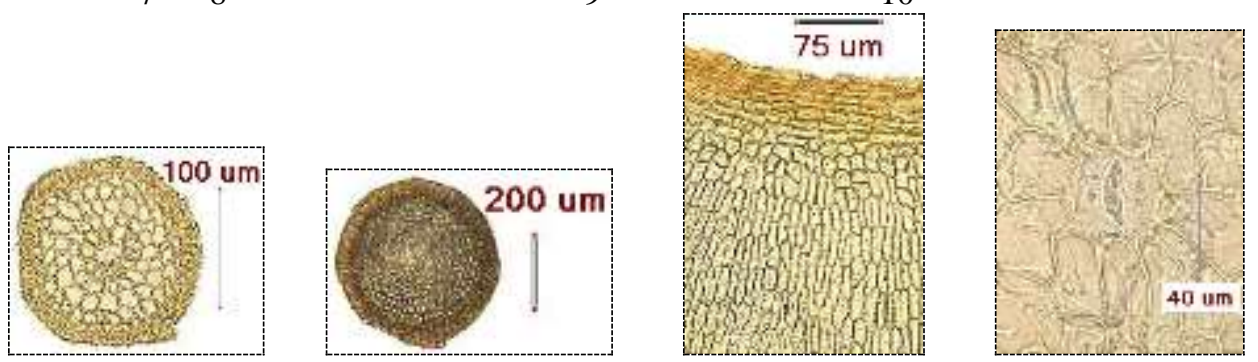

13

14

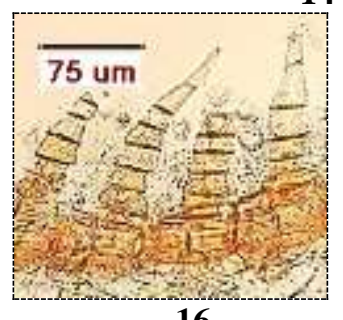

16

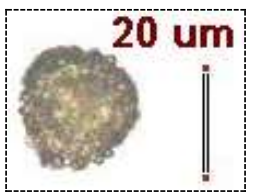

17

Plate (1). Entosthodon attenuatus (Dicks.) Bryhn: 1: A fruiting plant; 2: stem-leaf of $\bigcirc$ plant; 3: stem-leaf of $\delta$ plant; 4: Apex of $q$ plant leaf; 5: Leaf base of the same; 6: Subapical leaf margin; 7: T.S. of leaf; 8: T.S. of stem near apex; 9: T.S. of stem near base; 10: Calyptra; 11: T.S. of seta; 12: Operculum, top view; 13: Exothecium at rim; 14: Exothecium at apophysis showing a stoma; 15: T.S. of exothecium; 16: Peristome; 17: A spore. 
capsule erect, pyriform, with long neck, symmetric, up to $2.8 \mathrm{~mm}$; exothecium distinctly with bordered rim, exothecial cells linear-oblong to oblong, stomata cryptopore, outer tangential and radial walls very thick; peristome single, rudimentary, segmented, up to $160 \mu$ long; spores spheriodal, roughly papillose, golden brown, $18-22 \mu$ in diameter.

- Al-Hada region, about $14 \mathrm{~km}$ northwest to Taif city: side road off Al- Hada pelt way (site 3), between rocks of a vertical wall, $1950 \mathrm{~m}$, 24/1/2003. (U.2464c), associated with E. muhlenbergii.

- Al-Wakaf village, about $5 \mathrm{~km}$ west to Taif city (site 5): between rocks, 1750 m, 24/3/2003 (U.2796a, U.2800)

Earlier records: Hijaz mountains and El-Sarawat heights (Asir mountains according to Kürschner, 2000); Iq, Ir, IsP, Jo, Le, Om, Sy, Tu, Y\& UAE.

E. attenuatus, here, is \pm identical with that recorded in UAE (Shabbara \& El-Saadawi 2001) but both of them have some differences from those recorded in England (Smith, 2004), Northern America (Flowers, 1979) and Spain (Brugué, 2003). E. attenuatus in these three latter regions has nearly smooth spores, and shorter stems $(3-5 \mathrm{~mm})$. But short stems are also recorded in Arabian Peninsula (the artificial key of Kürschner, 2000). In addition to this, Frey \& Kürschner (1988) recorded cf. E. attenuatus from Yemen, which seems to have some different characters from typical. One can, therefore, conclude that two forms of E. attenuatus exist in the Arabian Peninsula.

\section{2-Entosthodon muhlenbergii (Turner) Fife Plate (2)}

Plants cladautoeciuos, yellowish green, loose turf. Stem fastigiated, erect with slightly pulvinate base, faint yellowish green but brown below, up to $7 \mathrm{~mm}$ long, with small central strand, homogenous, slightly angled to rounded elliptic in cross section. Leaves erect above but erecto-patent below, obovate, oblanceolate or spathulate, closely spaced above but distant below, sometimes comal, flat, up to $2.3 \mathrm{~mm}$ long (omitting apical cell); margin bluntly toothed to denticulate above especially old leaves but entire and with wide cells below, unistratose, pale; apex usually acuminate, with distinctly long apiculate cell; costa ending below apex delicate, usually with red pigment especially old leaves; areolation change \pm abrupt, cells hexagonal and pentagonal at apical and mid-leaf parts, up to $150 \mu \times 40 \mu$, 


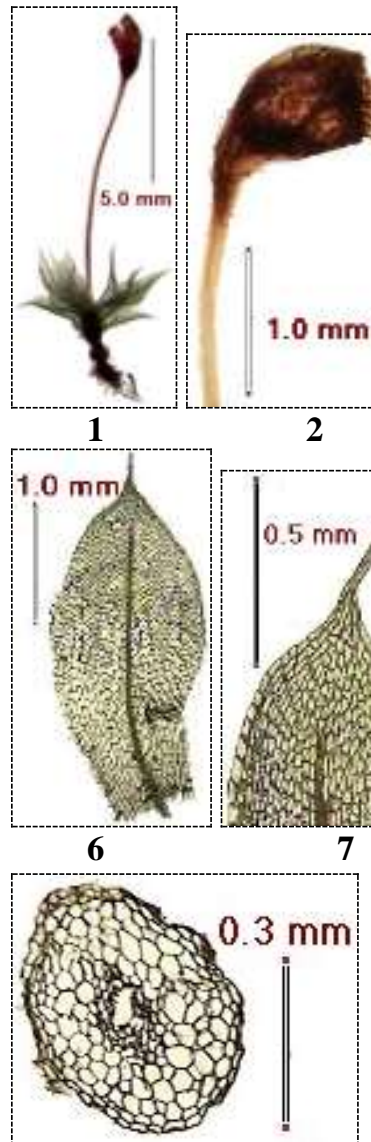

11

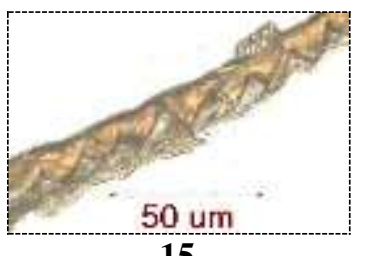

15

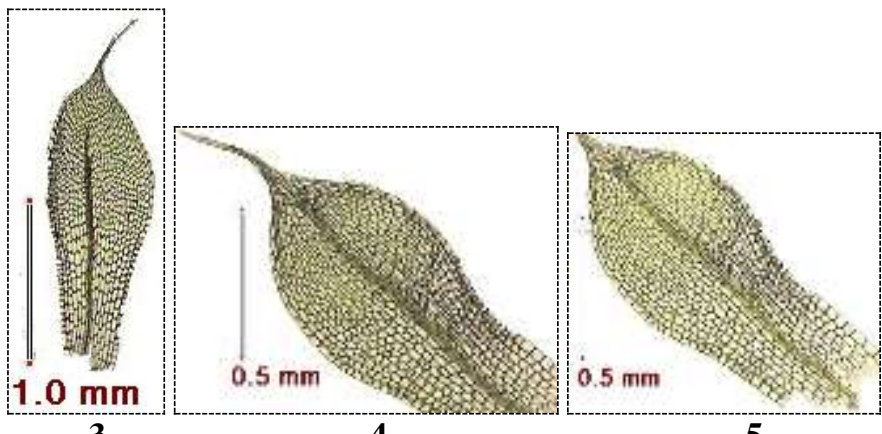

4

5
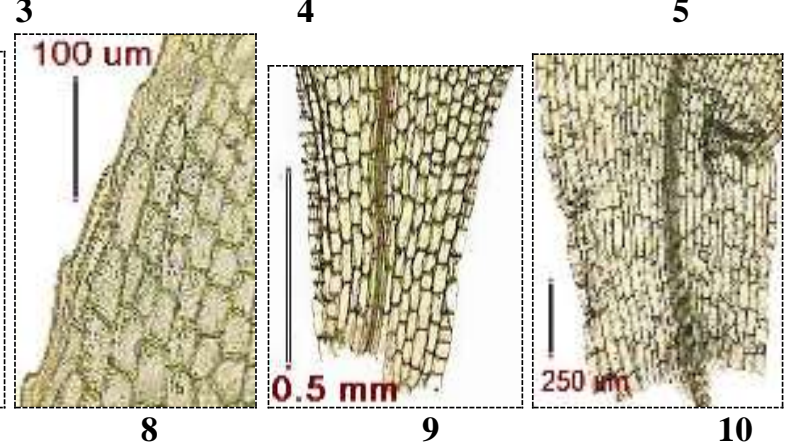

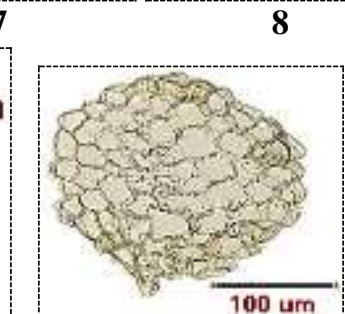

12

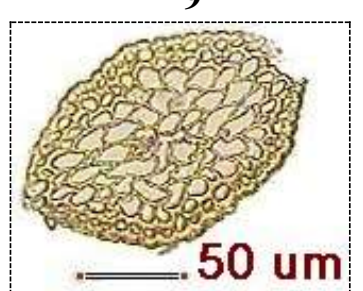

13

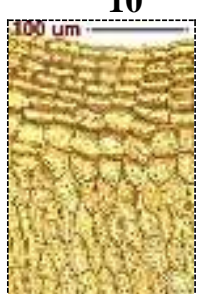

14

Plate (2). Entosthodon muhlenbergii (Turner) Fife: 1: A fruiting plant with broken capsule; 2: Capsule; 3, 4, 5, 6: Stem-leaves; 7: Leaf apex; 8: Leaf margin; 9, 10: Leaf bases; 11: T.S. of stem near apex; 12: T.S. of stem near base; 13: T.S. of seta; 14: Exothecium at rim; 15: T.S. of exothecium; 16: Peristome (outer and inner); 17: Spores. 
lax, large wide quadrate to long rectangular, up to $180 \mu$ x $30 \mu$ at base. Seta erect, slightly twisted when dry, with a small central strand and thick walled epidermis and outer cortical cells, up to $12 \mathrm{~mm}$ long; capsule slightly furrowed when dry, inclined to horizontal, gibbous, pyriforme, asymmetric, apophysis about half capsule length, up to $2.2 \mathrm{~mm}$; exothecial cells transversally rectangular at rim, longitudinal at mid-part, hexagonal and pentagonal at apophysis, stomata cryptopore, outer tangential and radial walls very thick, transition from capsule to neck slightly abrupt or sometimes gradually; annulus absent; operculum conical and mamillate, with slightly twisted brown cells; peristome double, well developed, up to $220 \mu$; spores spheriodal and planoconvex, papillose, $22-28 \mu$ in diameter.

- Al-Hada region; about $11.5 \mathrm{~km}$ northwest to Taif city: side road off Al-Hada pelt way (site 2), below and between rocks, $1950 \mathrm{~m}$, 14/3/2002. (U.2166b); about $14 \mathrm{~km}$ northwest to Taif city: side road off Al-Hada pelt way (site 3): between rocks of a vertical wall, 1950 m, 29/3/2002, 24/1/2003. (U.2228b, U.2463b \& U.2464b associated with E. attenuatus).

- Al-Shafa region; Wadi Al-Mohammadyah, about $17.5 \mathrm{~km}$ south to Taif (site 9): between rocks of a wall and on vertical and inclined substrate shaded by a large tree, $2150 \mathrm{~m}, 27 / 8 / 1999$ (U.1494a, U.1509a); Wadi Zee Ghazal, about $13 \mathrm{~km}$ south to Taif (site 7): below and between rocks, 2/1/2003 (U.2358b).

Earlier records: El-Sarawat heights (Asir mountains, according to Frey \& Kürschner, 1988); Iq, Ir, IsP, Jo, Le, Sy, Tu \& UAE.

All characters of E. muhlenbergii recorded in this work are within the range given for this species by Crundwell \& Nyholm (1974). But there are some differences between the present specimens and those recorded from UAE (Shabbara \& El-Saadawi, 2001) mainly in costa length, which ends just below the long apex in UAE while ending \pm far below apex in the present specimens, in basal cells of leaves which are longer in the Saudi specimens than in UAE, and in the presence of rhizoidal gemmae in UAE but not in Saudi Arabia. These three differences may be attributed to the great humidity which is found in the study area.

\section{3-Entosthodon pulchellus (H.Philib.) Brugués Plate (3)}

Plants dioecious, male "flowers" relatively obvious, loose turf. Stem branched, up to $0.6 \mathrm{~mm}$ long, with small central strand. Leaves of female 

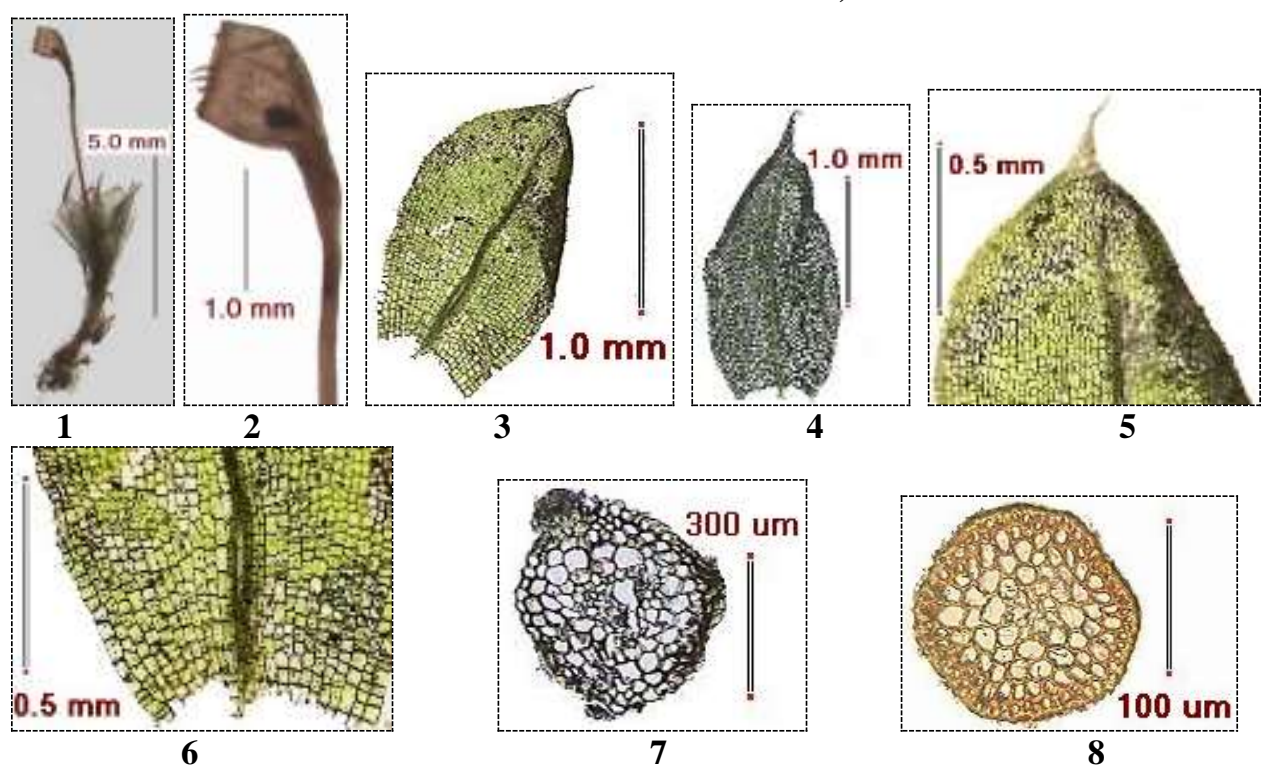

8
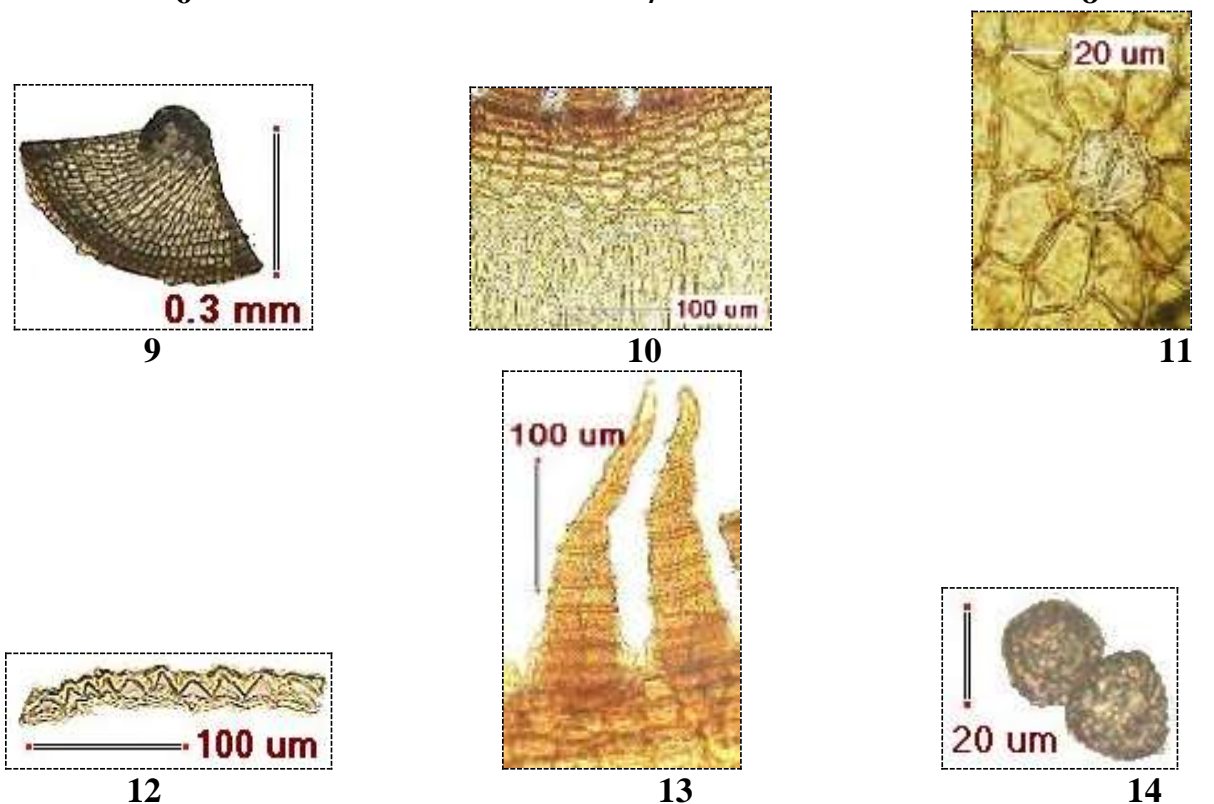

Plate (3). Entosthodon pulchellus (H. Philib.) Brugués: 1: a fruiting plant; 2: Capsule; 3, 4: Stem-leaves of $q$ plant; 5: Apex of $q$ plant leaf; 6: Leaf base of the same; 7: T.S. of stem near apex; 8: T.S. of seta; 9: Operculum, lateral view; 10: Exothecium at rim; 11: Exothecium at apophysis showing a stoma; 12: T.S. of exothecium; 13: Exostome; 14: Two spores. 
plants erecto-patent, ovate, obovate and lanceolate, comal, usually concave, up to $2.2 \mathrm{~mm}$ long; margin entire, unistratose, plane; apex obtuse with multicellular gradually tapering short point, costa ending below apex, slender; areolation usually \pm homogenous; cells hexagonal and pentagonal at apical and mid leaf parts up to $75 \mu \times 25 \mu$ but quadrate and rectangular at base to $60 \mu \mathrm{x} 40 \mu$. Sporophyte present; calyptra cuculate; seta erect, slightly twisted when dry, with a small central strand, thick walled epidermis and outer cortical cells, up to $7 \mathrm{~mm}$; capsule brown when mature, gibbous, pyriform, asymmetric, inclined to horizontal, slightly constricted below wide mouth, transition from capsule to neck \pm abrupt, apophysis less than half capsule length, up to $2 \mathrm{~mm}$ long; exothecium with transversely wide rectangular rim cells, stomata cryptopore, cells with very thick outer tangential and radial walls; annulus absent; operculum short conic, with broad mamilla, cells slightly twisted; peristome double, well developed, with hyaline tips, up to $280 \mu$; spores roughly papillose, $20-24 \mu$ in diameter.

- Al-Hada region, about $10.5 \mathrm{~km}$ northwest to Taif city, just a short distance after Mequat Wadi Mehrem (site1): on a vertical side of elevated land, 25/4/2003 (U.2899c).

- Al-Sail El-Kabeer, about $40 \mathrm{~km}$ north to Taif city, a few kilometers before Mequat Al-Sail (site 4): between rocks, 3/4/2003 (U.2862b).

- Al-Shafa region; Wadi Khomas, about $12 \mathrm{~km}$ south to Taif (site 6): on rocks, 23/8/2001 (U.2096a); Wadi Zee Ghazal, about 14 km south to Taif (site 8): below rocks on vertical side of elevated substrate, 8/6/2001(U.1962c).

Earlier records: Hijaz and El-Sarawat (Asir mountains according to Frey \& Kürschner, 1988); Jo, Om, Tu \& UAE,Ye.

Stem leaf of the studied specimens is somewhat wider than that of UAE specimens (Shabbara \& El-Saadawi, 2001). Sporophytes were not developed in UAE specimens to allow for comparison.

\section{Concluding remarks}

The three mosses reported in this work represent new records to the present study area. However, they are known to occur some distance to the north and to the south of the present study area in Hijaz mountains and ElSarawat heights respectively (Kürschner, 2000). This shows that extensive bryofloristical work undertaken by resident bryologists and covering as much as possible locations and habitats of Saudi Arabia would certainly improve our understanding of the bryoflora of this country and very likely 
adds new records or at least affords new distributional data. This in addition to the importance of providing illustrations and descriptions based on the study of native specimens which usually show some regional variation from descriptions based on the study of specimens from other regions of the world, as reported in this work for E. attenuatus which was shown to include two forms. The relatively low frequency of Funariaceae taxa in the study area probably compares well with their frequency in other parts of Saudi Arabia. However, Funariaceae is the fifth largest (regarding no. of spp.) family in Saudi Arabia proceeded by Pottiaceae, Bryaceae, Fissidentaceae and Grimmiaceae while followed by 14 other families.

It may be interesting to mention that the representation of Funariaceae in the western side of the Arabian Peninsula (four taxa in total) is lower than that in the eastern side (six taxa) (Funaria hygrometrica and Physcomitrium pyriform not included because they are introduced to Kuwait). Entosthodon attenuatus, E. muhlenbergii and E. pulchellus are the most widespread taxa in the two sides of the Arabian Peninsula. Entosthodon convexus, E. dureuri and E. fasicularis are restricted to the eastern side while Micropoma niloticum to the western one. More sound conclusions may be arrived at when the rest of the collection (1328 samples) is studied.

\section{Acknowledgements}

Sincere thanks are due to Prof. Dr. W. El-Saadawi, Botany Department, Faculty of Science, Ain Shams University for his illuminating criticism. Thanks to Mrs Marwa Wafiq, Assistant Lecturer, Botany Department, Faculty of Science for kind help with the legends of the plates.

\section{References}

Al-Shareif A. S. 1987. Geography of Saudi Arabian Kingdom. $1^{\text {st }}$ part (In Arabic). Dar El- Marreekh Pub. Al-Riyad-Kingdom Saudi Arabia.

Al-Welai'ee A.N. 1997. Geology and Geomorphology of the Saudi Arabian Kingdom (In Arabic). Second Edition, Fahd National Library Pub., ArRiyad, Saudi Arabian Kingdom.

Brown, G.F. 1960. Geomorphology of Western and Central Saudi Arabia. $21^{\text {st }}$ Int. Geol. Congr. Copenhagen Rep, 21: 150-159. Jackson R.O., Bogue, R.G. \& Maclean W.H. 1962. Geology of southern Hijaz quadrangle, Kingdom of Saudi Arabia. Map 1-210 
A, Ministry of Petrolium and Mineral Resources, Saudi Arabia and Department International USGS.

Brugués M. 2003. Key to the Funariales of the Iberian Peninsula and Balearic Islands. Cryptogamie, Bryologie 24 (1): 59-70.

Crundwell A.C. \& Nyholm E. 1974. Funaria muhlenbergii and related European species. Lindbergia 2: 222-229

El-Saadawi W. 1976. Some mosses from Kuwait. The Bryologist 79: 515518.

Fife A.J. 1985. A generic revision of the Funariaceae (Bryophyta: Musci). Part 1. Journal of the Hattori Botanical Laboratory 58: 149-196.

Flowers S. 1979. Mosses: Utah and West. Brigham Young University Press.

Frey W. and Kürschner H. 1988. Bryophytes of Arabian Peninsula and Socotra. Floristic, phytogeography and definition of the Xerothermic Pangaean element. Studies in Arabian Bryophytes 12. Nova Hedwigia 46: $37-120$.

Kürschner H. 2000. Bryophyte flora of the Arabian Peninsula and Socotra. Bryo. Biblio. 55: 1-131.

Kürschner H., Buck R.W. and Sollman Ph. 2001. Two tropical species new to the bryoflora of the Arabian Peninsula and Socotra 2. Nova Hedwigia 37: 253-259.

Refai M.S. 2001. New records to the Bryoflora of Saudi Arabia. Taeckholmia 21 (1): 35-44.

Smith A.J.E. 2004. The Moss Flora of Britain and Ireland. Second Edition, Cambridge University Press.

Shabbara H. \& El-Saadawi W. 2001. Our present knowledge of the bryoflora of United Arab Emirates. Taeckholmia 21 (1): 173-186.

Townsend C.C. 1978. Review of A.J.E. Smith " the moss flora of Great Britain and Ireland". Excerpta Bot. (A) 31: 398-400.

Wijk, R. Margadant, W.D. \& Florechiilz, P.A. 1959-69. Index Muscorum, $1-5$, Regnum vegetabie 17,26, 33, 48 \& 65. 